\title{
STUDI KELAYAKAN DAN DED PLTS KOMUNAL DI KABUPATEN SIGI
}

\author{
Maryantho Masarrang ${ }^{1}$ \\ ${ }^{1}$ Fakultas Teknik, Jurusan Teknik Elektro, Universitas Tadulako \\ 1antho.masarrang@gmail.com
}

\begin{abstract}
Therefore it's necessary to find solution and efforts to supply the electricily facilitics by utilizing the energy sources especially renewable energy as the power house, it is a solar power plant. Solar power plant is an alternative energy source that can convert sunlight into electrical energy by using photovoltaic. This research used load data at puro'o village, Sigi regency to determine the capacity of solar power plants's system. From the analysis of calculation, the overall total electrical load to be supplied was $393,598 \mathrm{Wh} /$ day or $393.59 \mathrm{kWh} / \mathrm{day}$, and the number of solar panels used was 459 units the connected in series and in parallel with the capacity of $250 \mathrm{Wp}$, the number of batteries to be used as many as 342 units were connected in series and parallel with a capacity 12 VDC 260 Ah, need battery charge regulator (BCR) was $436.56 \mathrm{~A}$, the used 11 units BCR with a capacity of $240 \mathrm{~V}$ 40 A..
\end{abstract}

\section{Keywords $\quad$ : Alternative Energy, Photovoltaic, Solar Power Plants}

\section{PENDAHULUAN}

Di Indonesia untuk kebutuhan listrik masyarakat menggunakan layanan PLN ( Perusahaan Listrik Negara ). Hampir semua masyarakat Indonesia dapat menikmati layanan listrik dari perusahaan tersebut. Kebutuhan energi yang terus meningkat dapat dijadikan sebagai indikator kemakmuran manusia, namun bersamaan dengan hal itu akan menimbulkan masalah dalam usaha penyediaanya. Untuk itu diperlukan upaya-upaya pengembangan teknologi yang mampu menyuplai kebutuhan energi dengan menggunakan energi terbarukan dan juga ramah lingkungan. Pembangkit listrik tenaga surya (PLTS) merupakan sumber energi alternatif yang dapat mengkonversikan sinar matahari menjadi energi listrik dengan menggunakan photovoltaic yang aman, bersih dan mudah digunakan dimanapun untuk memenuhi kebutuhan listrik untuk peralatan rumah tangga, penerangan, komputer, dll, terutama pada daerah yang belum terjangkau jaringan listrik. Khususnya, di desa Puroo Kecamatan Lindu Kabupaten Sigi.

Pembangkit listrik tenaga surya (PLTS) itu konsepnya sangatlah sederhana, yaitu mengubah cahaya matahari menjadi energi listrik. Panel sel surya merupakan modul yang terdiri beberapa sel surya yang digabung dalam hubungan seri dan paralel tergantung ukuran dan kapasitas yang 
diperlukan. Karena matahari bergerak, maka dengan posisi panel surya yang statis tidak akan diperoleh energi listrik yang optimal. Agar dapat terserap secara maksimum, maka sinar matahari itu harus diusahakan selalu jatuh tegak lurus pada permukaan panel surya. Pada siang hari, panel surya menerima cahaya (sinar) matahari yang kemudian diubah menjadi energi listrik oleh sel - sel kristal melalui proses photovoltaic. Listrik yang dihasilkan oleh panel surya dapat langsung disalurkan ke beban ataupun disimpan dalam baterai ACCU.

Sel Surya (Solar Cell) atau disebut juga photovoltaic cell (sel surya PV) adalah alat penghasil listrik secara langsung dari cahaya. Untuk mendapatkan tenaga listrik yang dibutuhkan, diperlukan serangkaian sel surya yang tergabung dalam bentuk panel sel surya (solar panel atau photovoltaic module). Tegangan listrik yang dikeluarkan panel sel surya ini umumnya beraliran DC. Jumlah dan kapasitas panel yang dibutuhkan tergantung pada beban alat listrik dan intensitas sinar matahari [1].

Pada umumnya kita menghitung maksimum sinar matahari sepanjang hari adalah 5 - 10 jam. Tenaga listrik yang dihasilkan disimpan dalam baterai, sehingga listrik bisa digunakan pada malam hari, dimana tanpa sinar matahari.

Battery charge regulator (BCR) merupakan komponen di dalam sistem PLTS berfungsi sebagai pengatur arus listrik (Current Regulator). Battery charge regulator (BCR) ini berfungsi untuk memastikan bahwa baterai berkerja dalam kondisi yang seharusnya. Pengatur ini menghindari penyimpanan (charge) atau pengeluaran (discharge) baterai yang berlebihan, yang keduanya sangat merusak umur baterai. Untuk menjamin charging dan discharging baterai yang baik, pengatur tersebut menjaga informasi kondisi penyimpanan daya (State of Charge atau SoC) baterai.

State of Charge (SOC) diukur berdasarkan pada tegangan sebenarnya dari baterai. Dengan mengukur tegangan baterai dan diprogram dengan tipe teknologi penyimpanan yang digunakan oleh baterai [2]. Baterai adalah alat untuk menyimpan daya yang dihasilkan oleh panel surya yang tidak segera digunakan oleh beban. Daya yang disimpan dapat digunakan saat periode radiasi matahari rendah atau pada malam hari.

Baterai juga akan mengeluarkan daya ketika penyinaran tidak cukup untuk menutupi kebutuhan beban ( karena variasi alami kondisi keikliman, awan, debu, dan lain-lain). Inverter yang berfungsi untuk merubah arus dan tegangan listrik DC (direct current) yang dihasilkan array PV menjadi arus dan tegangan listrik AC '(alternating current). Modul inverter juga dapat bekerja sebaliknya yaitu merubah listrik AC pada jaringan menjadi arus DC yang di masukkan ke dalam baterai [3]. 


\section{METODE PENELITIAN}

Dalam penelitian mengenai Studi Kelayakan dan Desain PLTS Komunal di Kabupaten Sigi, penulis menggunakan alat antara lain :

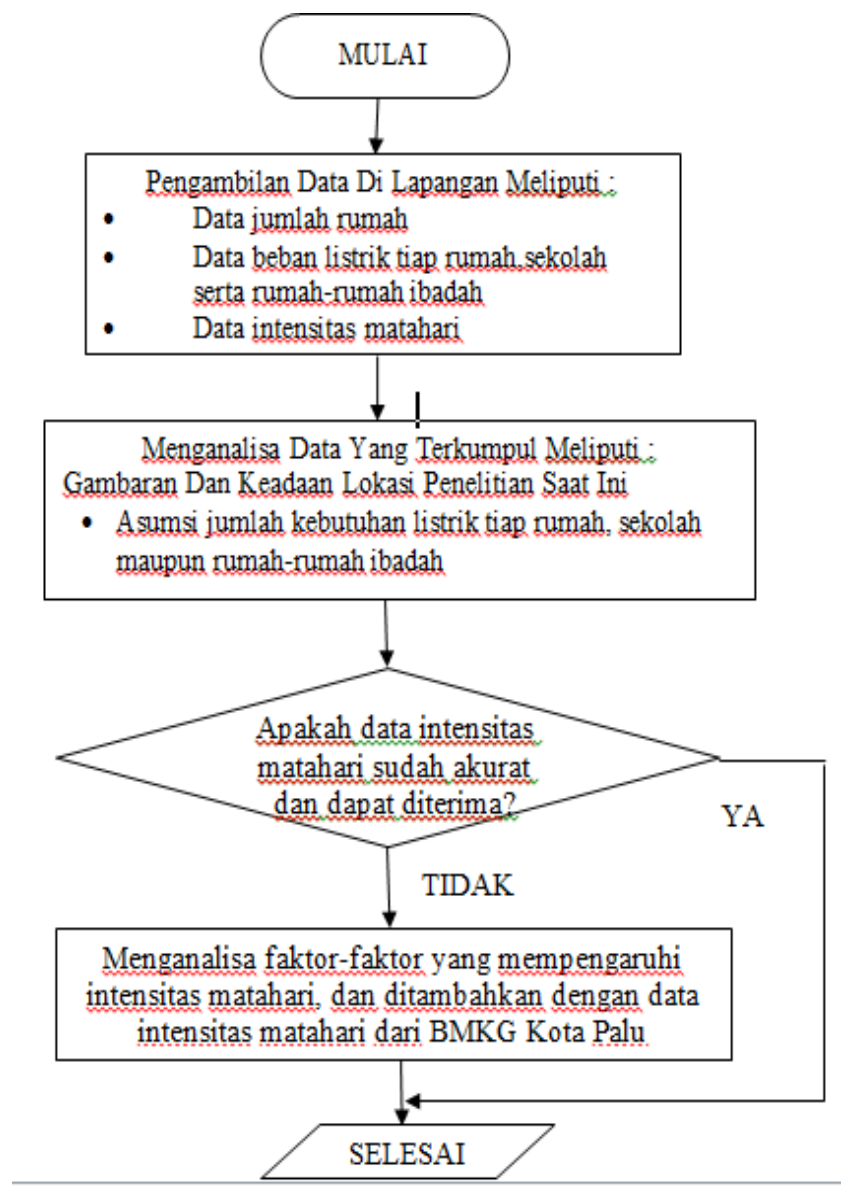

\section{HASIL DAN PEMBAHASAN}

\subsection{Hasil}

Dari hasil pengambilan data, maka dapat disajikan hasil dalam bentuk tabel berupa, data intensitas cahaya matahari serta asumsi kebutuhan listrik di tempat penelitian. 
3.1.1. Data rata-rata penyinaran matahari di Kabupaten Sigi

Untuk perencanaan Konstruksi Photovoltaic di desa Puroo kabupaten Sigi diperlukan data rata-rata penyinaran cahaya matahari, agar supaya daya yang dihasilkan maksimal dan sesuai dengan sistem yang dibutuhkan.

Tabel 1 : Data rata-rata penyinaran matahari (\%)

\begin{tabular}{|c|c|c|c|c|c|c|c|c|c|c|c|c|}
\hline Tahun & Jan & Feb & Mar & Apr & Mei & Jun & Jul & Ags & Sep & Okt & Nov & Des \\
\hline 2015 & 54 & 55 & 62 & 72 & 77 & 60 & 92 & 90 & 87 & 84 & 75 & 73 \\
\hline
\end{tabular}

Sumber: BMKG Stasiun Meteorologi Mutiara Palu

Berdasarkan data BMKG Stasiun Meteorologi Mutiara Palu, lamanya penyinaran matahari dalam satu hari diperkirakan selama 10 jam. Sehingga besarnya intensitas matahari dapat dihitung dengan mengalikan persentase penyinaran matahari dengan lamanya penyinaran matahari dalam sehari (suriadi dkk 2010).

$\mathrm{PSH}=$ rata-rata penyinaran matahari $(\%) \times$ lama penyinaran

$\mathrm{PSH}=54 \% \times 10=5.4$

$\mathrm{PSH}=55 \% \times 10=5.5$

$\mathrm{PSH}=62 \% \times 10=6.2$

$\mathrm{PSH}=72 \% \times 10=7.2$

$\mathrm{PSH}=77 \% \times 10=7.7$

$\mathrm{PSH}=60 \% \times 10=6.0$

$\mathrm{PSH}=92 \% \times 10=9.2$

$\mathrm{PSH}=90 \% \times 10=9.0$

$\mathrm{PSH}=87 \% \times 10=8.7$

$\mathrm{PSH}=84 \% \times 10=8.4$

$\mathrm{PSH}=75 \% \times 10=7.5$

$\mathrm{PSH}=73 \% \times 10=7.3$

\subsubsection{Menghitung Kebutuhan Energi Listrik}

Berdasarkan hasil survei, jumlah beban yang akan disuplai oleh PLTS Terpusat pada 225 unit rumah warga, 2 unit gedung sekolah, 3 unit gedung gereja, 1 unit gedung kantor desa, dan 1 unit gedung Poskedes adalah :

1. Jumlah pemakaian beban untuk rumah tipe $\mathrm{A}$

$E T=$ Pbeban $\times n \times$ lama pemakaian

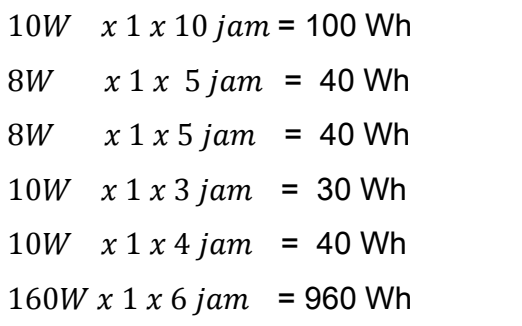


$160 \mathrm{~W} \times 1 \times 6 \mathrm{jam}=480 \mathrm{Wh}$

2. Jumlah Pemakaian beban untuk rumah tipe $\mathrm{B}$

$$
\begin{aligned}
& 10 \mathrm{~W} \times 1 \times 10 \mathrm{jam}=100 \mathrm{Wh} \\
& 8 \mathrm{~W} \times 1 \times 5 \mathrm{jam}=40 \mathrm{Wh} \\
& 8 \mathrm{~W} \times 1 \times 5 \mathrm{jam}=40 \mathrm{Wh} \\
& 8 \mathrm{~W} \times 1 \times 5 \mathrm{jam}=40 \mathrm{Wh} \\
& 10 \mathrm{~W} \times 1 \times 3 \mathrm{jam}=30 \mathrm{Wh} \\
& 10 \mathrm{~W} \times 1 \times 4 \mathrm{jam}=40 \mathrm{Wh} \\
& 160 \mathrm{~W} \times 1 \times 6 \mathrm{jam}=960 \mathrm{Wh} \\
& 160 \mathrm{~W} \times 1 \times 3 \mathrm{jam}=480 \mathrm{Wh}
\end{aligned}
$$

3. Jumlah pemakain beban untuk gedung gereja

$$
\begin{aligned}
& 8 \mathrm{~W} \times 2 \times 10 \mathrm{jam}=160 \mathrm{Wh} \\
& 12 \mathrm{~W} \times 6 \times 3 \mathrm{jam}=216 \mathrm{Wh} \\
& 160 \mathrm{~W} \times 2 \times 3 \mathrm{jam}=960 \mathrm{Wh}
\end{aligned}
$$

4. Jumlah Pemakaian beban untuk gedung sekolah dasar

$$
\begin{aligned}
& 8 \mathrm{~W} \times 3 \times 10 \mathrm{jam}=240 \mathrm{Wh} \\
& 8 \mathrm{~W} \times 7 \times 3 \mathrm{jam}=168 \mathrm{Wh} \\
& 160 \mathrm{~W} \times 2 \times 5 \mathrm{jam}=1,600 \mathrm{Wh} \\
& 8 W \times 2 \times 3 \mathrm{jam}=48 \mathrm{Wh}
\end{aligned}
$$

5. Jumlah pemakaian beban untuk Kantor Desa

$$
\begin{aligned}
& 10 \mathrm{~W} \times 2 \times 10 \mathrm{jam}=200 \mathrm{Wh} \\
& 8 \mathrm{~W} \times 1 \times 3 \mathrm{jam}=24 \mathrm{Wh} \\
& 8 \mathrm{~W} \times 1 \times 3 \mathrm{jam}=24 \mathrm{Wh} \\
& 8 \mathrm{~W} \times 2 \times 3 \mathrm{jam}=48 \mathrm{Wh} \\
& 160 \mathrm{~W} \times 2 \times 3 \mathrm{jam}=960 \mathrm{Wh}
\end{aligned}
$$

Setelah mengasumsikan jumlah kebutuhan listrik, maka dapat di ketahui total keseluruhan beban yang akan di suplay oleh PLTS adalah sebagai berikut :

- Beban untuk perumahan tipe $A=(175 \times 1.690)=295.750 \mathrm{Wh} / \mathrm{hari}$

- Beban untuk perumahan tipe $B=(50 \times 1.730)=86.500 \mathrm{Wh} /$ hari

- Beban untuk gedung gereja $=(3 \times 1.336)=4.008 \mathrm{Wh} /$ hari

- Beban untuk gedung SD $=2.056 \mathrm{Wh} /$ hari

- Beban untuk gedung PAUD = 1.332 Wh / hari

- Beban untuk gedung Poskesdes $=2.696 \mathrm{Wh} /$ hari

- Beban untuk gedung kantor desa $=1.256 \mathrm{Wh} /$ hari

Jadi, total beban keseluruhan adalah sebagai berikut $393.598 \mathrm{Wh} /$ hari. 
Total daya beban ( Watt ) :

- Daya beban untuk perumahan tipe A $\quad(175 \times 366)=64.050$ Watt

- Daya beban untuk perumahan tipe B $(50 \times 374)=18.700$ Watt

- Daya beban untuk gedung gereja

$(3 \times 408)=1.224$ Watt

- Daya beban untuk gedung SD $=416$ Watt

- Daya beban untuk gedung PAUD = 374 Watt

- Daya beban untuk gedung Poskesdes $=524 \mathrm{Watt}$

- Daya beban untuk gedung kantor desa = 372 Watt

Jadi, total beban yang terpasang (Watt) adalah sebagai berikut 85.660 Watt.

Berdasakan nilai intensitas cahaya matahari yang akan dipergunakan adalah nilai intensitas cahaya matahari rata-rata terendah, yaitu 5,4. Pemilihan intensitas matahari berada pada nilai yang paling rendah, agara konstruksi photovoltaic yang akan direncanakan tetap dapat memenuhi besar energi yang akan disuplai pada beban. Karena besar kebutuhan beban untuk desa Puroo yang akan disuplai oleh kontruksi Photovoltaic adalah $393.598 \mathrm{Wh} /$ hari dengan total daya 85.660 Watt atau $85,6 \mathrm{~kW}$ dengan tegangan kerja $220 \mathrm{~V}$.

\subsubsection{Menghitung Jumlah Panel Surya}

Untuk menghitung besar total arus dan tegangan digunakan persamaan sebagai berikut (James P Dunlop,2010) :

larray $=\frac{E c r i t}{\eta \text { batt } x \text { VSDC x } t P S H}$

$I_{\text {array }}=\frac{393.598}{0,9 \times 220 \times 5,4}=\frac{393.598}{1.069,2}=368,1 \mathrm{~A}$

Karena desa Puroo juga merupakan daerah yang berada tepat digaris khatulistiwa serta pemasangan panel yang di rencanakan adalah posisi sejajar, maka dapat diasumsikan bahwa besar faktor pengotorannya adalah $90 \%$.

$$
\begin{aligned}
& \text { Irated }=\frac{\text { I array }}{\mathrm{Cs}} \ldots \ldots \ldots \ldots . . . . . \\
& \text { Irated }=\frac{368,1}{0,90}=409 \mathrm{~A}
\end{aligned}
$$

Untuk mengetahui jumlah panel photovoltaic yang akan di rangkai secara pararel, dapat dihitung dengan persamaan sebagai berikut ini :

Jumlah Panel Paralel $=\frac{\text { Irated }}{\text { IMP }}$

Jumlah Panel Paralel $=\frac{409}{8,02}=51$ unit panel (dibulatkan) 
Untuk mengetahui besar tegangan panel photovoltaic yang dibutuhkan maka dapat dihitung dengan menggunakan persamaan berikut :

Vrated $=1,2 \times\{($ VSDC $-[$ VSDC $\times$ C\%V $\times($ Tmax - Tref $)]\}$

Vrated $=1,2 \times\{(220-[220 \times-0,004 \times(47-40)]\}=271,39 \mathrm{~V}$

Untuk mengetahui berapa jumlah panel photovoltaic yang akan dirangkai seri, dapat dihitung dengan persamaan sebagai berikut :

Jumlah Panel Seri $=\frac{\text { Vrated }}{\text { VMP }}$

Jumlah Panel Seri $=\frac{271,39}{31,2}=9$ Unit (dibulatkan)

Dari hasil perhitungan di atas, maka jumlah panel surya yang akan dirangkai secara pararel sebanyak 51 unit dan jumlah panel yang dirangkai secara seri sebanyak 9 unit, sehinggal total panel surya yang digunakan adalah 459 unit dengan kapasitas $250 \mathrm{Wp}$.

\subsubsection{Menghitung kapasitas dan jumlah baterai Panel Surya}

Waktu cadangan yang dibutuhkan pada cuaca mendung adalah selama 2 hari dan berdasarkan total kapasitas beban serta waktu hari - hari otonomi maka kapasitas baterai yang dibutuhkan dapat dihitung sebagai berikut :

$B_{\text {out }}=\frac{\text { Ecrit } x \text { ta }}{V S D C}$

$B_{\text {out }}=\frac{393.598 \mathrm{~W} / \mathrm{hari} \times 2 \mathrm{hari}}{220 \mathrm{~V}}=3.578,16 \mathrm{Ah}$

Karena deep of discharge (DOD) baterai yang digunakan sebesar $80 \%$, maka total kapasitas baterai yang dibutuhkan adalah sebagai berikut :

$B_{\text {rated }}=\frac{\text { Bout }}{D O D}$

$B_{\text {rated }}=\frac{3.578,16}{0,80}=4.472,7 \mathrm{Ah}$

Untuk mengetahui jumlah baterai yang digunakan dapat diperoleh dengan menggunakan persamaan sebagai berikut :

Jumlah baterai $=\frac{\text { Brated }}{\text { kapasistas per baterai }(\mathrm{Ah})}$

Jumlah baterai $=\frac{4 \cdot 472,7 \mathrm{Ah}}{260 \mathrm{Ah}}=17,2$ unit (dibulatkan menjadi 18 unit baterai paralel).

Perhitungan tersebut merupakan jumlah baterai berdasarkan kapasitas, berikut jumlah baterai berdasarkan voltase $\frac{220 \mathrm{~V}}{12 \mathrm{~V}}=18,3$ unit (dibulatkan menjadi 19 unit baterai seri).

Jadi, jumlah baterai yang digunakan adalah sebanyak 342 unit baterai dengan kapasitas masing-masing baterai $260 \mathrm{Ah}$, dengan tegangan $12 \mathrm{~V}$. Dengan jumlah 
baterai yang dirangkai secara paralel adalah 18 unit, jumlah tersebut merupakan hasil pembulatan dari 17,2 untuk mencukupi arus baterai yang dibutuhkan, dan baterai terangkai secara seri 19 unit, jumlah tersebut merupakan hasil pembulatan dari 18,3 untuk mencukupi tegangan baterai yang dibutuhkan.

\subsubsection{Menghitung Kapasitas Baterai Charger Regulator (BCR)}

Untuk mendapatkan jumlah $B C R$ yang dibutuhkan maka dilakukan perhitungan sebagai berikut :

Kapasitas BCR = Jumlah Modul Surya (Paralel) $\times$ Isc

Kapasitas $\mathrm{BCR}=51 \times 8,56=436,56 \mathrm{~A}$

Dari perhitungan yang dilakukan maka diketahui besar kapasitas battery charger regulator (BCR), yang digunakan adalah 436,56 A. Karena dalam perancangan ini akan digunakan BCR dengan kapasitas $40 \mathrm{~A}$, sehingga di butuhkan BCR sebanyak 11 unit yang dihubung secara paralel.

\subsubsection{Menghitung Kapasitas Inverter}

Pada pemilihan inverter di upayakan kapasitas kinerjanya mendekati kapasitas daya yang dibutuhkan agar kinerja inverter menjadi lebih maksimal. Berdasarkan perhitungan yang telah dilakukan daya yang harus disuplay $85.660 \mathrm{Watt} /$ hari dan total pemakaian (Wh) adalah 393.598 Wh / hari, sehingga dipilih inverter berkapasitas 90 $\mathrm{kW}$ dengan tegangan input $220 \mathrm{VDC}$ dan tegangan output $380 \mathrm{VAC}$.

\subsubsection{Ukuran Penghantar}

Untuk menentukan diameter penghantar yang digunakan, penulis mengacu pada PUIL 2000 tabel 7.3-5b (hal.305) dengan rumus sebagai berikut :

a. Ukuran penghantar dari panel surya ke BCR

Total arus dari panel surya ke BCR adalah sebagai berikut

$I_{p v}=I s c \times$ Jumlah modul paralel $\times 125 \%$

$l_{p v}=8,56 \times 51 \times 125 \%=545,7 \mathrm{~A}$

Jadi, jenis kabel yang digunakan dari panel surya ke BCR adalah kabel NAYHSY yang berdiameter $300 \mathrm{~mm}^{2}$.

b. Ukuran penghantar dari BCR ke Inverter

Besar arus input dari BCR ke inverter adalah sebagai berikut :

$$
\begin{aligned}
I_{\max }= & \frac{P a c}{V \min \times \pi i n v} \\
& =\frac{90000}{220 \times 0,98}=417,4 \mathrm{~A}
\end{aligned}
$$


Jadi, jenis kabel yang digunakan dari BCR ke Inverter adalah kabel NAYHSY yang berdiameter $240 \mathrm{~mm}^{2}$

c. Ukuran penghantar output inverter

loutlnverter $=\frac{\text { Daya maximum inverter }}{\text { tegangan output inverter }}$

lout Inverter $=\frac{90.000}{380}=236,8 \mathrm{~A}$

Jadi, jenis kabel yang digunakan output Inverter adalah kabel NAYSEY yang berdiameter $150 \mathrm{~mm}^{2}$.

\subsubsection{Rugi - Rugi Daya}

Dalam sebuah perancangan pembangkit listrik, tentu ada rugi-rugi daya yang dihasilkan. Adapun rugi - rugi daya yang dihasilkan dibagi menjadi 2 jalur yaitu jaringan yang mengarah ke timur dengan panjang $500 \mathrm{~m}$ dan jaringan yang mengarah ke barat dengan panjang $800 \mathrm{~m}$. Untuk menentukan rugi-rugi daya terlebih dahulu kita menentukan arus yang mengalir pada masing - masing jaringan.

\subsubsection{Sistem Grounding}

Penulis menggunakan system grounding nilai standar yang mengacu pada Persyaratan Umum Instalasi Listrik atau PUIL 2000 (peraturan yang sesuai dan berlaku hingga saat ini) yaitu kurang dari atau sama dengan 5 (lima) ohm. Nilai sebesar $5 \mathrm{ohm}$ merupakan nilai maksimal atau batas tertinggi dari hasil resistan pembumian (grounding) yang masih bisa ditoleransi. Nilai yang berada pada range 0 $5 \mathrm{ohm}$ adalah nilai aman dari suatu instalasi pembumian grounding. Nilai tersebut berlaku untuk seluruh sistem dan instalasi yang terdapat pembumian (grounding). Dan material untuk kabel penghantar yang digunakan adalah jenis kabel BC/BBC, yaitu memiliki luas penampang $>/=50 \mathrm{~mm}^{2}$ (PUIL $2000: 68$ ).

\section{KESIMPULAN}

Berdasarkan hasil penelitian dan perhitungan potensi surya di desa Puroo Kecamatan Lindu Kabupaten Sigi, maka dapat ditarik beberapa kesimpulan yaitu:

1. Dari hasil survei ke lokasi penelitian maka diketahui daya yang dibutuhkan (Watt) adalah 85.660 Watt, dan total keseluruhan pemakaian beban adalah $393.598 \mathrm{Wh} / \mathrm{hari}$.I

2. Total jumlah panel photovoltaic yang akan menyuplai beban adalah 51 unit dirangkai secara paralel dan 9 unit dirangkai secara seri, sehingga total panel surya yang digunakan adalah 459 unit dengan kapasitas $250 \mathrm{Wp}$. 
3. Total jumlah baterai yang dibutuhkan adalah sebanyak 342 unit baterai dengan kapasitas masing - masing baterai adalah 12 VDC 260 Ah, dimana baterai yang dirangkai secara paralel berjumlah 18 unit dan yang dirangkai secara seri 19 unit.

\section{DAFTAR PUSTAKA}

[1]. Alief rakhman, 2013, Jenis Sistem PLTS, http://rakhman.net/2013/04/jenis-sistem-plts.html, diakses : Tanggal 10 Agustus 2015.

[2]. Anonim, 2016. www.alibaba.com/product-detail/90kw-Top-quality-frequency-inverterconverter. Diakses : 23 Februari 2016.

[3]. Asy'ari, H, Jatmiko, \& Angga. 20102. INTENSITAS CAHAYA MATAHARI TERHADAP DAYA urusan Teknik Elektro, Fakultas Teknik, Universitas Muhammadiyah Surakarta.

[4]. Dunlop, P.J, 2010. Photovoltaic Systems, second edition. American Technical Publisheks.

[5]. Mohammad Sidik Boediyono.2012, POTENSI DAN PERANAN PLTS SEBAGA/ ENERGI ALTERNATIF MASA DEPAN DI INDONESIA, Volume 14, No.2, Jurnal Sains dan Teknologi Indonesia. 